\title{
Understanding The Basic of Kanji's Meaning through Mnemonic Method Learning
}

\author{
Linna Meilia Rasiban \\ Universitas Pendidikan Indonesia \\ linnameilia@upi.edu
}

\begin{abstract}
It is commonly assumed and claimed that learners with no prior knowledge of Chinese characters often find it more difficult to learn kanji than learners from character backgrounds (Ishida, 1986; Machida, 2000; Toyoda, 1995). It makes kanji being a burden or something dreaded by Indoneian JFL. According to Hayashi \& Yano (1994), Kanji has a lot of characters and the foreigners who do not use to handling such large sets of character in everyday life is not used to it, so it's hard to remember. This research is to answer the question about the difficulty of Indonesian JFL to memorize the meaning of events in Japanese kanji. This study uses mix method design with 30 Indonesian JFL the second semester students of Japanese education department Indonesia University of Education. The results of the analysis revealed that leaning Kanji through mnemonic method seemed to help students to understand kanji's meaning and the way to read it. The statement was also supported by the students' response saying that the learning process with Mnemonic method was interesting and enjoyable.
\end{abstract}

Keywords: mnemonic, association technique, Shokyuu Hyouki (Basic Kanji Writing)

\section{INTRODUCTION}

The learning of kanji or Chinese characters is considered to be one of the most challenging problems faced by learners of Japanese as a second/foreign language (hereafter JFL/JSL learners) (Gamage, 2003). According to Gamage (2003), the typological differences between kanji and alphabets are assumed to be responsible for this difficulty (Bourke, 1996; Flaherty, 1993; Toyoda, 1998; Watanabe \& Toyoda, 1994 in Gamage, 2003). Kanji is one of the most difficult parts in learning Japanese especially for students who do not use kanji in their language (Grainger, 2005). This is because to read and write in kanji they have to know kun-yomi, to read Kanji in Japanese, whereas on-yomi is a system to read kanji in Chinese (Heisig \& Sienko, 2008, p. 11)

Although, there is a plenty of books published to help memorizing Kanji, but most students only memorize successfully the words, but in a short time they forget it easily because kanji is not used in their daily life (Rasiban, 2012). This is because there are approximately 2,000 characters of Kanji used in daily life in Japan and the foreigners are not used to handling such large sets of character (Hayashi \& Yano, 1994 in Jin, 2012, p. 181). Based on the previous study (2013) through observation and interview with students who have got Shokyuи Hyouki 2, the result showed similar outcome that most of students could only remember Kanji in the short time. Nevertheless, students hardly remember kanji after the learning process in the next meeting, due to various ways to read each of Kanji word. Such situation was supported by the data from questionnaires given to third semester students of Japanese Language Education Department, Faculty of language and Literature, UPI (Indonesia University of Education). It was found that $80 \%$ of the students who took Shokyuи hyouki 2 courses met some difficulties to remember kanji's meaning and memorize the way of how to read it.

At present, the method used in the Japanese learning still use handout and workbook/worksheet. Though the result of weekly quiz is good, the students still found it hard to remember kanji's meaning and the way of writing it both in the mid-term exam and final exam. It can be seen from the results of mid-term and final-exam of the third semester students in academic year of 2011/2012.

This research was a follow up of the previous research (Rasiban, 2012) concerning an attempt to remember kanji's meaning through association in basic Kanji learning. The findings revealed that learning kanji by associating it with pictures made it easily remembered and seemed to help the students in memorizing kanji's meaning. Therefore, this study followed up the previous research by using a similar technique applied in different level of students. In addition, kanji materials were improved from the basic level of kanji to the medium one (Shokyu Zenhan). However, some weaknesses found in the previous study were due to multi interpreted pictures displayed as learning media. Consequently, this underlined the improvement of teaching media focusing on pictures association and kanji analogue which were understandable by the majority of students.

\section{Learning Model by Using Mnemonic Method with Association Technique}

In general, Mnemonic is a technique that facilitates students remember something, particularly the method which needs a formula or statement used to help others remember something (Kamus Besar Bahasa Indonesia). Wang and Thomas (1996, p.104) defined mnemonics as “. . . learning strategies that make elements of abstract information more familiar and encourage students to form meaningful association to these familiar elements." More generally, mnemonics can be defined as learning strategies, comprising either visual images or words, that can enhance memorization and recall of information. According to Stine, Mnemonic is a brain's ability to connect words, idea and imagination (Rasiban, 2012). Based on the definitions above, mnemonic is defined as a technique used to help the other people remember something through creating formula or statement or 
connecting words, ideas and imaginations. In other words, mnemonic means a technique which optimally uses memory in particular ways. Widiatmoko (2008, p. 51) claimed that Mnemonic method may seem to be playable, but it is useful to remember new information unfamiliar to our brain, for example to remember vocabulary of all foreign languages including Latin.

The use of Mnemonic give benefits to the learning process since the barrier disappeared. The method will encourage students' motivation because it can make the students participate in their learning process more actively, so that the optimal result can be achieved by the students. Therefore, the goal of using Mnemonic with association technique was proposed to achieve the optimal result of learning.

Researchers have questioned whether pictures provide more information than words during the memory coding processes, or vice versa (Mayer \& Anderson, 1992; Mayer \& Sims, 1994; Rieber, 1991; Towers \& Anglin, 1994). Rose study (2013) found that while mnemonics are useful to memorize kanji and kanji components when applied in a meaningful way, an overreliance on this strategy can have negative effects for the learner. The study highlighted numerous accounts of the meaning of a kanji being lost in overly complex mnemonic strategies.

There are some techniques used in applying mnemonic method for memorizing (Bobby, 2003) that is Cantol technique/Rhyme, Location technique, Acronym technique and Association technique. Since remembering kanji for early Japanese language learners is inappropriate and difficult, the study focused on learning kanji through picture association technique which was necessary to be implemented.

In this picture association technique, the following is how kanji is formed:

1. Shiji moji, kanji formation by asserting a particular abstract.

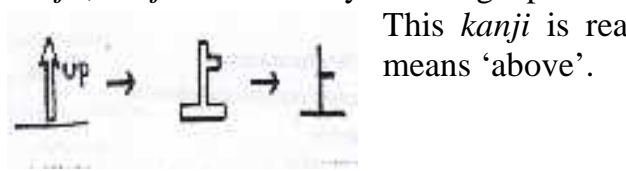

2. Shouki moji, kanji formation by imitating picture of particular thing or nature.

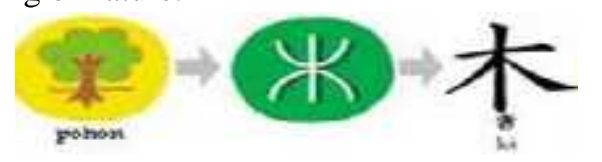

This kanji was read ' $k i$ ' which means 'tree'.

3. Kaii moji, kanji formation by combining two or more things of basic kanji.

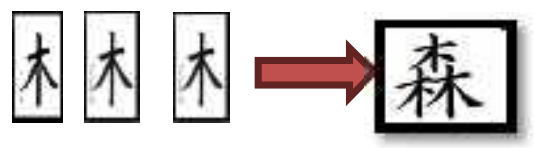

Based on the previous research (Rasiban, 2010), it was found that leaning through association technique was adequately effective, since the learners were easy to memorize kanji. However, the lack of pictures as media used in adopting picture association and Story Manabu Kanji 300 (Beuckmann, 2008) and Kanji Look and Learn (Banno, 2011) was insufficiently understood by the students because of the meaning which were adopted was Japanese philosophy.

On the other side, the second research (Rasiban, 2012) showed that the use of associated media and analogue were independently made by Indonesian people without adopting the book Story Manabu Kanji 300 (Beuckmann, 2008) that can be seen in the following points,

(1) Kanji was associated from the meaning adapted from its kanji's form, for example, Kanji 'yuki' which means 'snow'.

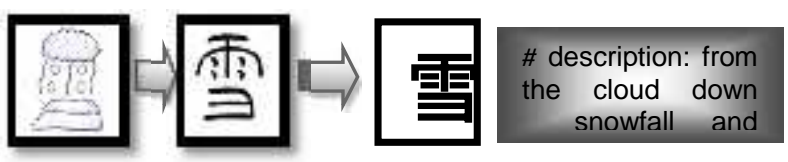

(2) There was some kanji which was described from its form related to the Indonesian's meaning. For example, kanji 'gou' which means 'number', since kanji writing of ' $g o u$ ' if the letter was reversed, it is similar to 'NO' which means number.
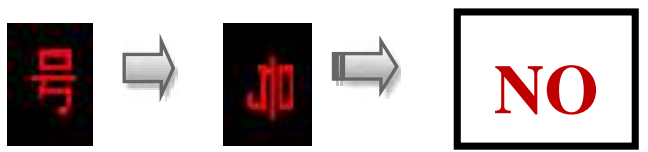

(3) There was kanji that couldn't be connected either to its meaning (as explained in no (1)) or from its letter writing (as explained in no (2)). So it was made from the description of story and the displayed picture that described its story. For example kanji 'oriru” which means 'down', it was explained and described at the same time in the form of story.
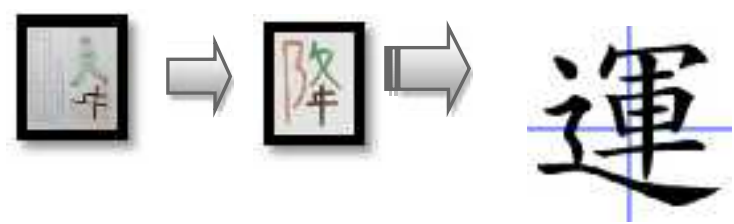

Besides explaining kanji through Mnemonic method above, learning to write kanji is was also important. The sequence of writing kanji (kakijun) was adopted from website www.yamasa.org by using flash as the media in power point. I can be put in this example,

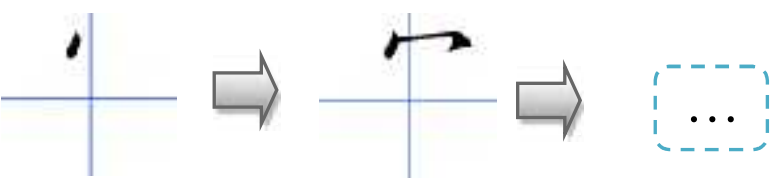

2. Method

This research was a mix method research as a combination between qualitative and quantitative one (Ivankova and Cresswell, 2009, p. 137). The method was chosen to answer the research questions of the study. The first question was 
related to the students ' ability in remembering kanji's meaning which was obtained through qualitative method. While the second question was dealing with students" response toward learning model and the effectiveness of teaching media gained from the qualitative method. The research design was adopted from the action research method proposed by Susanto (2010) as can be seen below:

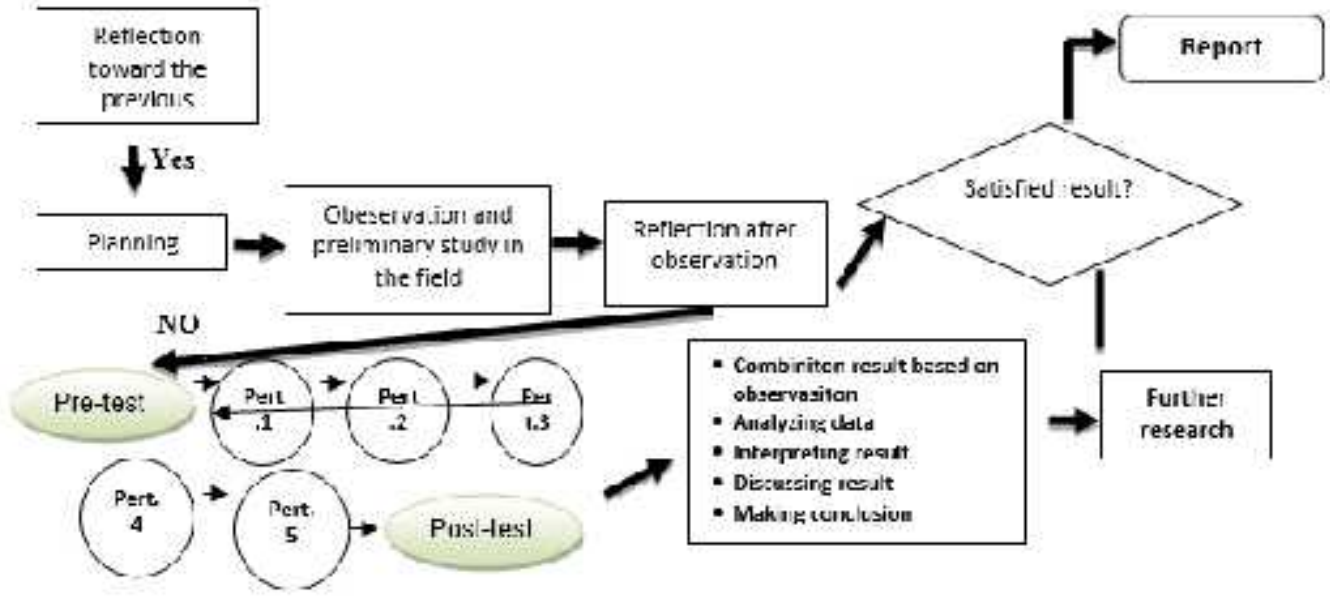

Figure 1. Research Design

The subjects of the reseach were the second semester students of Japanese education department who were taking shokyuu hyouki 2. The samples of the study were 2B class with 30 students. The study was conducted from February to May 2013 with 7 times of meeting which were devided into 2 meetings for pre-experiment, and pre test, post test and filling questionaire. Five meetings were allocated for giving treatments to the basic kanji by using Mnemonic method. Data were colleted through pre-test and post-test, questionnaire, and interview with students regarding their responses to using power point as media in Shokyuu learning 3 through mnemonic method joined with association technique.

\section{Findings and Discussion}

The respondent's ability to remember kanji's meaning was measured by the pre-test and post-test. The average score of pre-test was 70 while the average score of post -test was 86 . The graphic can be seen as below.

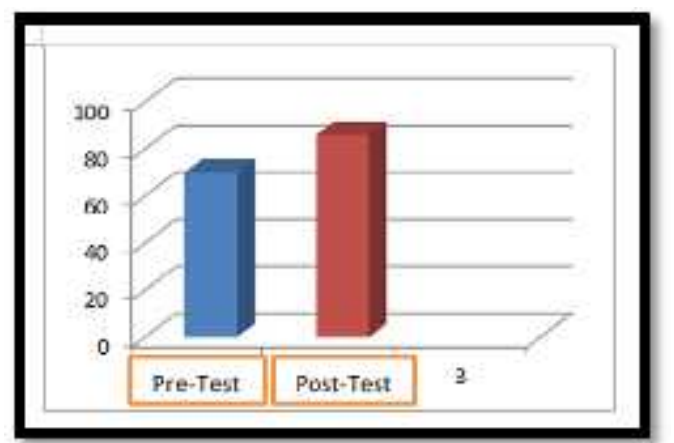

Figure 2. Average score of pre test and post test

It could be concluded that in general the results of class average score improved 16 points and also the individual's score. The result was supported by the questionnaire and interview stating that the respondents admitted kanji tended to be easier to be memorized since the students were helped by Mnemonic method. Besides, this technique seemed to be effective for memorizing and writing kanji during exam or test. The respondent's comprehension toward kanji's meaning displayed in power point could be seen from game or exercise given after introducing kanji. Almost $90 \%$ students could understand and remember easily the meaning of kanji through pictures association displayed in power point as its media.

The finding from the interview with respondents was implemented to support the result from the test. Most of them said that using power point as media in Shokyuu Hyouki 2 learning combining with the Mnemonic method and association technique helped respondents remember kanji's meaning easily in a short time which was similar to the findings gained in the previous research. According to Bellezza (1981), mnemonics act as mediators between the learning stimuli and the information to be remembered, and are used later by the learner to recall information through a self-cueing process. It was supported by the respondents' statement in the interview that this learning technique helped them to write kanji during post-test easily, especially the ones found in the instructions asking them to write kanji from kanji's part (bushu) and write kanji into Indonesian language.

In a previous study (Rasiban, 2010) regarding the recall effort kanji meaning through association techniques in learning basic kanji. The results showed that learning kanji to associate into a memorable image and facilitate their memory in remembering the kanji meaning. One of the advantages is to assist and facilitate students in answering questions in final test.

But previous research had found that the media image that is displayed is the notion of the philosophy of the Japanese people, which mostly has less comprehensible meaning for Indonesian JFL.

$$
\beta+\hookrightarrow+\text { 元 }=\beta \text { 完 } \rightarrow \beta \text { 完 }
$$


For example, kanji "in" that has meaning institutions, associated by Beuckmann (2008: 154) that 'if you want a healthy body condition (better $\beta$ ) need to go to a hospital or health institution'. Associated like this (Beuckmann, 2008: 154).

Association of images and analogies story is poorly understood by most Indonesian JFL in Japanese Language Education Department, Indonesia University of Education (Rasiban, 2010). Because the function of mnemonic techniques is to facilitate remembering associate quickly, then the research this time is to revise the existing image associated with the image created in accordance with the philosophy of the Indonesian people.

\section{CONCLUSION}

It can be concluded that learning kanji through a combined technique between mnemonic and power point seemed to be effective to improve the students' comprehension, in remembering the basic kanji's meaning. The success of using this media depended on explanation of kanji's meaning constructed through story so that the students were able to understand and remember kanji easily. The respondents' understanding toward kanji associated to its meaning was found to be high since they were easier to remember rather than the one which didn't use power point as its media. It influenced the students in completing the test because they could write kanji easier. Although the strategies they use mostly are the most helpful strategies, in contrary to the widespread belief that repeated writing is a time consuming and tedious task, JFL learners seemed to believe that strategies associated with repeated writing are the most helpful in learning kanji (Gamage, 2003).

Based on the interview result, it referred that most of the respondents said that the learning media helped students in remembering the kanji's meaning. Besides, it may create a new learning atmosphere for the students since most of kanji learning was boring and difficult. However the method changed the class to be enjoyable and interesting one. This learning model also eases the students to complete questions in the test. Overall by using this method, this study contributed a new alternative teaching method in basic kanji learning. Meanwhile, the weakness of this mnemonic method with association techniques was due to unsolved problem regarding the students' difficulties in remembering the way of reading kanji either kun-yomi or on-yomi. Therefore the further research is expected to find the effective method for remembering the way of reading kanji for both kun-yomi and on yomi.

\section{Acknowledgement}

Researcher gratitude goes to students of Japanese language education department FPBS UPI academic year of 2010/2011who participated in the early research and students of Japanese language education department FPBS UPI academic year of 2011/2012. A big thanks also for seniors who have given suggestion, critics, and guidance until this research can be done successfully. And to all parties who have contributed to this research.

\section{REFERENCES}

Banno, E. et.al., (2011). Kanji look and learn (512 kanji with illustrations and mnemonic hints). Japan: The Japan Times.

Bellezza, A. S., (1981). Mnemonic devices: Classification, characteristics, and criteria. Review of Educational Research, 51(2), 247-275.

Beuckmann, Fusako et. al., (2008). Story Manabu kanji 300. Japan : Kurosio Shuppan.

Bobby, D., Mike, H., (2003). Quantum learning. Bandung : Kaifa.

Gamage, G. H. (2003). Perceptions of kanji learning strategies: Do they differ among Chinese character and alphabetic background learners? Research Online: University of Wollongong Australia.

Grainger, P. (2005). Second language learning strategies and Japanese: Does orthography make a difference? System 33, 327-339. http://dx.doi.org/10.1016/j.system.2005.01.003.

Heisig, J. W., \& Sienko, T. (2008). Remembering the kanji 3: Writing and reading Japanese characters for upper-level profiency. University of Hawaii Press: Foreign Language Study.

Ivankova, N. V., \& Creswell, J. W. (2009). Mix Methods. In J. Heigham, \& R. A. Croker (Eds.), Qualitative research in applied linguistics: A practical introduction. Palgrave Macmillan, New York, NY.

Jin, Q. (2012). Intelligent learning systems and advancements in computer-aided instruction. Waseda University, Japan: Information Science Reference.

Mayer, R. E., \& Anderson, R. B. (1992). The instructional animation: helping students build connections between words and pictures in multimedia learning. Journal of Educational Psychology, 84(4), 444-452.

Mayer, R. E., \& Sims, V. K. (1994). For whom is a picture worth a thousand words? Extensions of a dual-coding theory of multimedia learning. Journal of Educational Psychology, 86(3), 389-401.

Rasiban, L. M. (2010). Model pembelajaran mnemonic sebagai salah satu upaya untuk mengingat makna pada pembelajaran shokyu hyouki. Penelitian tindakan kelas di jurusan Pendidikan Bahasa Jepang FPBS UPI: tidak diterbitkan.

Rasiban, L. M. (2012). Mengingat kanji melalui teknik asosiasi dalam metode mnemonic. Jurnal Pendidikan Bahasa Jepang ASPBJI Korwil Jabar "Wa", 5(1), 19797982,

Rieber, L. P. (1991). Animation, incidental learning, and continuing motivation. Journal of Educational Psychology, 83(3), 318-28.

Rose, H. (2013). L2 learners' attitudes toward, and use of, mnemonic strategies when learning Japanese kanji. The Modern Language Journal, 97, 4, (2013). 
Susanto. (2010). Konsep penelitian tindakan kelas dan penerapannya. Surabaya: Unesa.

Towers, R. L., \& Anglin, G. J. (1994). The instructional effectiveness of computer-aniimated and static visuals. Paper presented at the annual meeting of the
Association for Educational Communications and Technology, Nashville, TN.

Wang, A. Y., \& Thomas, M. H. (1996). Mnemonic instruction and gifted child. Roeper Review, 19(2), 104-05.

Widiatmoko, I. (2008). Super great memori. Jakarta: Gramedia. 